\title{
Investigation on Physicochemical Properties of Wastewater Grown Microalgae Methyl Ester and its Effects on CI Engine
}

\author{
Sara TAYARI ${ }^{1 *}$, Reza ABEDI ${ }^{2}$, Ali ABEDI ${ }^{3}$ \\ ${ }^{1}$ Faculty of Environment and Energy, Islamic Azad University Science \& Research Branch, Tehran, Iran \\ ${ }^{2}$ MLC Research and Development Center, MAPNA Group Co., Tehran, Iran \\ ${ }^{3}$ Faculty of Mechanical Engineering, Tarbiat Modares University, Tehran, Iran
}

\begin{abstract}
Microalgae have been mentioned as a promising feedstock for biodiesel production. In this study, microalgae Chlorella vulgaris (MCV) was cultivated in a bioreactor with wastewater. After biodiesel production from MCV oil via transesterification reaction, chemical and physical properties of MCV methyl ester were evaluated with regular diesel and ASTM standard. Besides, engine performance and exhaust emissions of CI engine fuelled with the blends of diesel-biodiesel were measured. The GC-MS analysis showed that oleic and linoleic acids were the main fatty acid compounds in the MCV methyl ester. Engine test results revealed that the use of biodiesel had led to a major decrease in $\mathrm{CO}$ and $\mathrm{HC}$ emissions and a modest reduction in $\mathrm{CO}_{2}$ emissions, whereas there was a minor increase in $\mathrm{NO}_{x}$ emissions. Furthermore, there was a slight decrease in the engine power and torque while a modest increase in brake specific fuel consumption which are acceptable due to exhaust emissions reduction. The experimental results illustrate considerable capabilities of applied MVC biodiesel as an alternative fuel in diesel engines to diminish the emissions.
\end{abstract}

Keywords - Chlorella vulgaris; engine performance; exhaust emissions; microalgae; wastewater.

\begin{tabular}{|ll}
\hline Nomenclature & \\
BSFC & Brake specific fuel consumption \\
$\mathrm{B}(\mathrm{X})$ & $\mathrm{X} \%$ biodiesel + (100-X) \% diesel \\
$\mathrm{CO}$ & Compression ignition \\
$\mathrm{CO}_{2}$ & Carbon monoxide \\
$\mathrm{FAME}$ & Carbon dioxide \\
$\mathrm{HC}$ & Fatty acid methyl ester \\
$\mathrm{KOH}$ & Hydrocarbon \\
$\mathrm{HTL}$ & Potassium hydroxide \\
$\mathrm{MCV}$ & Hydrothermal liquefaction \\
$\mathrm{MCV} 10$ & Microalgae Chlorella vulgaris \\
$\mathrm{MCV} 20$ & $10 \%$ MCV biodiesel and $90 \%$ diesel \\
$\mathrm{NO}_{\mathrm{x}}$ & $20 \%$ MCV biodiesel and $80 \%$ diesel \\
\hline
\end{tabular}

* Corresponding author.

E-mail address: Sara.tayari@gmail.com 


\section{INTRODUCTION}

In recent years, owing to population growth, increasing people prosperity and development of technologies, energy demand has increased which results in environmental pollution. Therefore, research for finding proper substitute energy has been done and through chemical and biochemical analyses, biofuels have been introduced with various feedstocks as a significant alternative to replace transportation fuels [1], [2]. Based on feedstocks and production, four generations have been evolved in biofuels.

Microalgae are considered to be one of the best options and attractive feedstocks for biodiesel production, which has higher lipid content and growth rate, lower environmental impact and productivity in unsuitable land and wastewater compared with other generation [3]-[7]. This substance has high $\mathrm{CO}_{2}$ sequestration capability [8], [9]; moreover, it can apply the biotechnology modifications to adjust the environments of cultivation [10], [11]. About 72,500 algae species have been discovered [12] with different characteristics, for instance, some of them have high lipid content but low cell growth, such as Botryococcus braunii and other ones have high growth rate as Chlorella vulgaris [13]. The lipid content for microalgae Chlorella vulgaris has been estimated to be appropriate for industrial production which is about $40-50 \%$ [14]. According to the outputs of some experimental studies, the photobioreactor size and shape, suitable temperature, proper mixing process, depth of light penetration and $\mathrm{CO}_{2}$ supply as a vital component in photosynthesis can improve the biomass productivity and the amount of carbon absorption coefficient [15]-[19]. The biomass remaining after oil extraction can be applied as fertilizers to boost the properties of arable land or it can be used as animal food.

Compared to other fatty acid methyl esters (FAMEs), microalgae biodiesel is claimed to have lower calorific values whereas its cetane number, viscosity and density are higher [19]-[25]. As a result of the higher cetane number in biodiesel, easier auto-ignition would occur [26]. Higher viscosity has several impacts on biodiesel evaporation, spray, and atomization which leads to longer combustion duration [27]. Chen et al. [28] and Satputaley et al. [29] experiments showed that the physical and chemical properties of microalgae methyl ester were in the range of ASTM standards. There are a few studies on considering emissions and performance of the engine while applying microalgae biodiesel as a fuel. Table 1 shows some of these investigations.

TABLE 1. REVIEW OF RESEARCHES IN ENGINE EMISSIONS AND PERFORMANCE FUELLED WITH MICROALGAE BIODIESEL

\begin{tabular}{|c|c|c|c|c|c|c|c|c|}
\hline \multirow{2}{*}{$\begin{array}{l}\text { Microalgae } \\
\text { feedstock }\end{array}$} & \multirow{2}{*}{ Reference } & \multirow{2}{*}{$\begin{array}{l}\text { Biodiesel } \\
\text { blends }\end{array}$} & \multirow{2}{*}{$\begin{array}{l}\text { Engine } \\
\text { operation }\end{array}$} & \multicolumn{4}{|c|}{ Emissions \% (vs diesel) } & \multirow{2}{*}{$\begin{array}{l}\text { Engine } \\
\text { power }\end{array}$} \\
\hline & & & & NO $_{x}$ & HC & $\mathrm{CO}$ & $\mathrm{CO}_{2}$ & \\
\hline $\begin{array}{l}\text { Chlorella } \\
\text { cohnii }\end{array}$ & Islam et al. [30] & $\begin{array}{l}\text { B10, B20, } \\
\text { B50 }\end{array}$ & $\begin{array}{l}2000 \mathrm{rpm}, \\
25 \% \text { to full } \\
\text { loads }\end{array}$ & $\begin{array}{l}22 \\
\text { for B50 }\end{array}$ & $\begin{array}{l}-50 \\
\text { for B50 }\end{array}$ & - & - & - \\
\hline \multirow[t]{2}{*}{ Chlorella sp. } & $\begin{array}{l}\text { Makareviciene } \\
\text { et al. [25] }\end{array}$ & B30 & $\begin{array}{l}1500 \mathrm{rpm}, \\
\text { full load }\end{array}$ & 0 & $\begin{array}{l}-25 \\
\text { to }-5\end{array}$ & -10 & - & - \\
\hline & $\begin{array}{l}\text { Al-lwayzy et } \\
\text { al. [14] }\end{array}$ & $\mathrm{B} 100, \mathrm{~B} 20$ & $\begin{array}{l}3670 \mathrm{rpm} \text {, } \\
\text { full load }\end{array}$ & -60.94 & - & - & -11.6 & -15.1 \\
\hline \multirow[t]{2}{*}{$\begin{array}{l}\text { Chlorella } \\
\text { vulgaris }\end{array}$} & Patel et al. [31] & $\begin{array}{l}\text { B10, B15, } \\
\text { B20 }\end{array}$ & $\begin{array}{l}\text { Variable } \\
\text { load }\end{array}$ & 38 & -31 & -20 & - & - \\
\hline & $\begin{array}{l}\text { Mwangi et al. } \\
\text { [32] }\end{array}$ & B2 & $\begin{array}{l}2200 \mathrm{rpm}, \\
50 \% \text { load }\end{array}$ & 2 & -50.2 & -0.34 & - & - \\
\hline
\end{tabular}




\begin{tabular}{|c|c|c|c|c|c|c|c|c|}
\hline \multirow{2}{*}{$\begin{array}{l}\text { Microalgae } \\
\text { feedstock }\end{array}$} & \multirow{2}{*}{ Reference } & \multirow{2}{*}{$\begin{array}{l}\text { Biodiesel } \\
\text { blends }\end{array}$} & \multirow{2}{*}{$\begin{array}{l}\text { Engine } \\
\text { operation }\end{array}$} & \multicolumn{4}{|c|}{ Emissions \% (vs diesel) } & \multirow{2}{*}{$\begin{array}{l}\text { Engine } \\
\text { power }\end{array}$} \\
\hline & & & & $\mathrm{NO}_{\mathrm{x}}$ & $\mathrm{HC}$ & $\mathrm{CO}$ & $\mathrm{CO}_{2}$ & \\
\hline & $\begin{array}{l}\text { Mathimani et } \\
\text { al. [33] }\end{array}$ & $\begin{array}{l}\text { B30, B40, } \\
\text { B50, B60 }\end{array}$ & $\begin{array}{l}1500 \mathrm{rpm}, \\
\text { full load }\end{array}$ & $\begin{array}{l}-1 \\
\text { for B50 }\end{array}$ & $\begin{array}{l}-13 \\
\text { for B50 }\end{array}$ & $\begin{array}{l}-40 \\
\text { for B50 }\end{array}$ & $\begin{array}{l}-18.6 \\
\text { for B50 }\end{array}$ & - \\
\hline & $\begin{array}{l}\text { Kumar et al. } \\
\text { [28] }\end{array}$ & $\begin{array}{l}\text { B10, B15, } \\
\text { B20 }\end{array}$ & $\begin{array}{l}\text { Variable } \\
\text { load }\end{array}$ & $\begin{array}{l}38 \\
\text { for B20 }\end{array}$ & $\begin{array}{l}-31 \\
\text { for B20 }\end{array}$ & $\begin{array}{l}-20 \\
\text { for B20 }\end{array}$ & - & - \\
\hline \multirow[b]{2}{*}{$\begin{array}{l}\text { Chlorella } \\
\text { protothecoides }\end{array}$} & $\begin{array}{l}\text { Al-lwayzy et } \\
\text { al. [34] }\end{array}$ & $\begin{array}{l}\text { B20, B50, } \\
\text { B100 }\end{array}$ & $\begin{array}{l}1700 \text { to } \\
2900 \mathrm{rpm}\end{array}$ & -2.4 & - & -12.3 & -0.7 & -1.2 \\
\hline & $\begin{array}{l}\text { Satputaley et } \\
\text { al. [35] }\end{array}$ & B100 & $\begin{array}{l}\text { 1500rpm, } \\
\text { variable } \\
\text { load }\end{array}$ & -13 & -27 & -31 & - & -3.09 \\
\hline $\begin{array}{l}\text { Chaetoceros } \\
\text { gracilis }\end{array}$ & $\begin{array}{l}\text { Wahlen et al. } \\
\text { [36] }\end{array}$ & B100 & $\begin{array}{l}2500 \text { to } \\
3700 \mathrm{rpm} \text {, } \\
\text { no-load }\end{array}$ & -24 & -30 & -17.4 & 2.6 & -7 \\
\hline Not declared & $\begin{array}{l}\text { Tuccar et al. } \\
\text { [24] }\end{array}$ & B20 & $\begin{array}{l}1200 \text { to } \\
2800 \mathrm{rpm}\end{array}$ & 10 & - & -8 & - & -2.7 \\
\hline
\end{tabular}

In these studies, a significant reduction in almost all gaseous emissions were reported by using microalgae biodiesel blends except for $\mathrm{NO}_{\mathrm{x}}$ emissions. Some studies stated an increase in $\mathrm{NO}_{\mathrm{x}}$ emissions [24], [28], [30], [31], [37] with biodiesel injection whereas others reported a reduction [14], [34]-[36]. Singh et al. [38] compared marine microalgae and Jatropha biodiesel. Their test results showed that $\mathrm{NO}_{\mathrm{x}}$ emissions of microalgae were $17 \%$ lower than Jatropha biodiesel. Hossain et al. [39] tested microalgae biodiesel which extracted through hydrothermal liquefaction (HTL) at a low-speed diesel engine. Their analyses showed that microalgae methyl ester had a reduction in engine power, $\mathrm{CO}$, and $\mathrm{CO}_{2}$, whereas $\mathrm{NO}_{x}$ emissions were increased compared with pure diesel. In most studies, the brake specific fuel consumption (BSFC) of microalgae biodiesel increased and the engine performance reduced compared with pure diesel [30]-[36].

Though certain reports are available on microalgae biodiesel based effects on CI engine, these studies were conducted under the limited operating conditions for performance and emission profiles, especially $\mathrm{CO}$ and $\mathrm{NO}_{x}$ emissions. In this paper, the physical and chemical properties of MCV biodiesel and its effects on the CI engine were investigated by using different MCV biodiesel blends at different engine speeds/loads. Thus, quantities of methyl ester were produced with $\mathrm{KOH}$ catalyst from MCV biomass which was cultivated in the photobioreactor. The physicochemical properties of MCV biodiesel were determined and compared with ASTM standards. Then, the performance and exhaust emissions of the single-cylinder engine were investigated while using different diesel-biodiesel blends at different engine speeds/loads. The outputs compared with each other and pure diesel. This research confirms using microalgae biodiesel as an outstanding alternative fuel in the CI engine with minor changes.

\section{Material AND MethodS}

Chlorella vulgaris can be considered as one of the high lipid content feedstock for biodiesel which contains $50 \%$ lipid and the size of Unicellular is 5-10 $\mu \mathrm{m}$ [40]. As a result of low-risk contamination and low rate water evaporation, Chlorella vulgaris was cultivated and produced in a photobioreactor device. To advance biological growth, the parameters such as $\mathrm{CO}_{2}$ and water supply, $\mathrm{pH}$ levels, culture density, temperature, and photosynthetic can be 
improved within the system [41]. This chapter describes the materials and methods applied throughout this study and consists of the three major experimental parts which include a description of microalgae cultivation and biomass production, description of lab-scale procedures for conversion of MCV oils to FAMEs, and explanation of the experimental test setups for the using MCV biodiesel in CI engine.

\subsection{Microalgae Cultivation and Biomass Production}

The most common device for microalgae cultivation is the tubular photobioreactors [42]. Thus, $50 \mathrm{ml}$ of Chlorella vulgaris species containing $2.5 \cdot 106$ of cells were added to the photobioreactor with $0.6 \mathrm{~m}^{2}$ surface and then were placed in phototeron room. Nitrogen and phosphorous besides other micronutrients are the essential nutrients for growth and cultivation of microalgae. Besides, MCV has the potential to remove them from highly concentrated nutrient-rich wastewater. The wastewater sample which was collected from municipal drains was evaluated for toxicity and amount of chemical oxygen, nitrogen and phosphorous. The results showed that the amount of oxygen demand was sufficient in wastewater sample, however, nitrogen and phosphorous were not adequate for cultivation. Thus, some nutrients were added to processes for accelerating cultivation and producing valuable biomass. In this study, nutrients and water were circulated by a centrifugal pump which was operated at $200 \mathrm{rpm}$. The required light for cultivation was provided by projectors and set at $230 \mu \mathrm{mol} \cdot$ photon $/\left(\mathrm{m}^{2} \cdot \mathrm{s}\right)$. Furthermore, the photobioreactor was equipped with an automatic heating and cooling system that controlled the temperature. The optimum temperature for microalgae cultivation was obtained at $25^{\circ} \mathrm{C}$. There is a complex relationship between $\mathrm{CO}_{2}$ condensation and $\mathrm{pH}$. The most appropriate $\mathrm{pH}$ for microalgae cultivation is 7.2 [43] and $\mathrm{KNO}_{3}$ and urea were used for $\mathrm{pH}$ fluctuating at this range. A photobioreactors process system for cultivation of microalgae is shown in Fig 1.

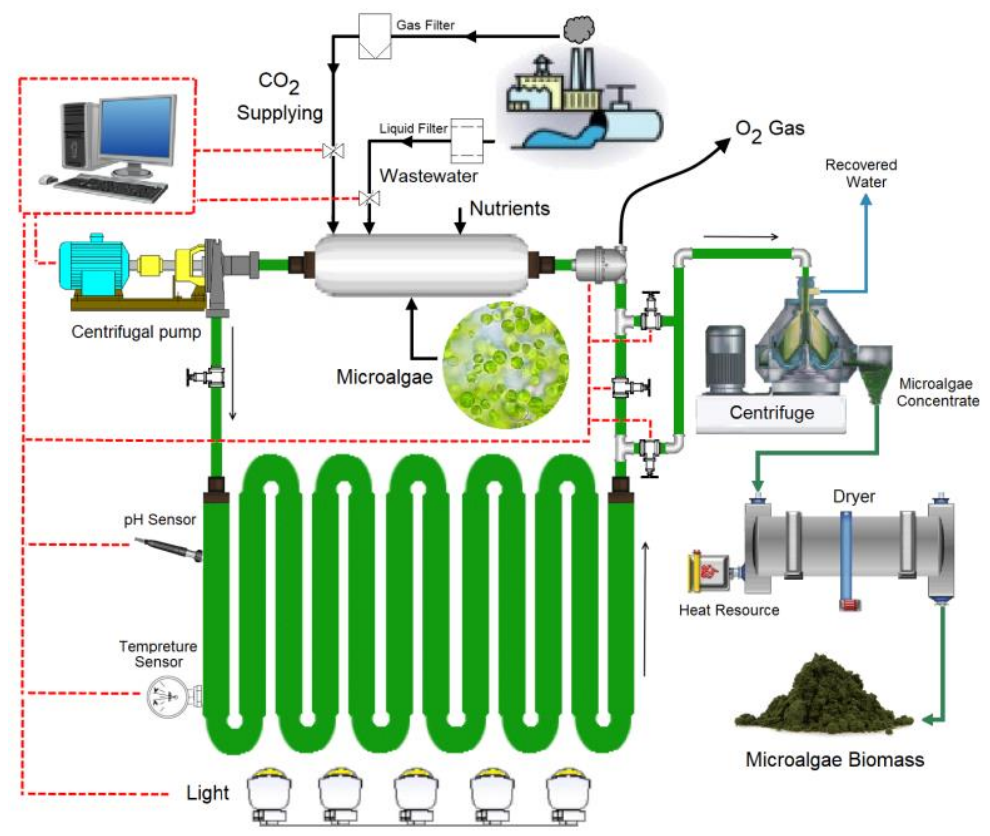

Fig. 1. MCV cultivation and biomass production processes. 
With an increase in the number of microalgae, due to the consumption of nutrients and low penetration of light into the lower parts, the growth of microalgae was stopped and their density remained stable. At this stage, harvesting for a sufficient amount of microalgae was initiated. Then, a centrifuge machine (Allegra X-22r model) was applied at $2000 \mathrm{rpm}$ for $10 \mathrm{~min}$ to separate biomass from the liquid. The collected biomass was dried at $60{ }^{\circ} \mathrm{C}$.

\subsection{Oil Extension and Methyl Ester Production}

The process of oil extension and biodiesel production are shown in Fig. 2. The Soxhlet solvent apparatus was applied for obtaining the microalgae lipid. In this process, MCV biomass was situated in a reservoir located of Soxhlet and solvent was heated to the boiling point which is approximately $70{ }^{\circ} \mathrm{C}$ for about 4 hours. The solvent for this experiment was the mixture of $n$-Hexane and isopropanol in the ratio of 1:2. The mixture of solvent soaked the MCV biomass and dissolved its lipids. The rotary device was used for separating oil from the solvent-based. The result showed that for gaining $500 \mathrm{ml}$ oil, $1.5 \mathrm{~kg}$ of biomass was required.

The transesterification reaction was applied to produce methyl ester derived from MCV oil. In this process, methanol ( $1 \%$ oil weight) and $\mathrm{KOH}$ as the catalyst were added to the oil. The reaction was conducted for two hours at $65-70{ }^{\circ} \mathrm{C}$ and stirred at $400 \mathrm{rpm}$. After the reaction time, the combination of methyl ester, glycerol, and other products such as glyceride were achieved. For isolating the glycerol as the valuable by-product, the flask content was poured into the separating funnel for several hours at $25^{\circ} \mathrm{C}$ [44]. For removing unreacted methanol and catalysts, deionized water was used for the leaching of final products.

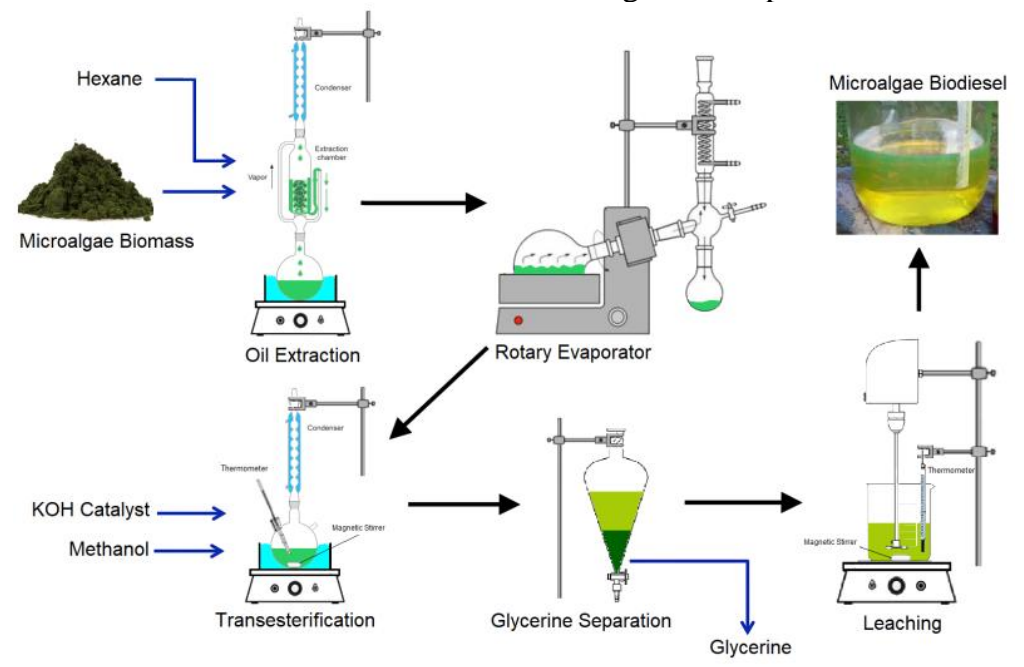

Fig. 2. Process description to produce microalgae biodiesel.

\subsection{Test setup}

Fig. 3 shows the tested CI engine which was placed in the laboratory of the Agriculture Faculty at Tarbiat Modares University. A single-cylinder CI engine the specifications of which are summarised in Table 2 was coupled to a dynamometer and AC alternator. The performance and exhaust emissions were determined for each MCV biodiesel blend at various engine speed (2000-3000 rpm). For each sample, the engine was tested in the non-load, 
half-load, and full-load conditions. The exhaust gas emissions $\left(\mathrm{CO}, \mathrm{CO}_{2}, \mathrm{HC}\right.$, and $\left.\mathrm{NO}_{\mathrm{x}}\right)$ were determined by Tester MGT5.

Owing to achieving the accurate results, the injection pressure was adjusted; moreover, air and oil filters and lubrication oil were changed for each sample. Furthermore, the engine test ran to consume the remaining fuel from previous tests and to reach the steady-state concentration of exhaust gas amount.

TABLE 2. SPECIFICATIONS OF DIESEL ENGINE

\begin{tabular}{ll}
\hline Parameters & Specifications \\
\hline Engine model & 3 LD 510 Lombardini \\
Engine type & 4-Stroke, direct injection, diesel engine \\
Cylinder number & 1 \\
Stroke volume, cc & 510 \\
Compression ratio & $17.5: 1$ \\
Maximum power, HP@rpm & $12 @ 3000$ \\
Maximum torque, N-m@rpm & $32.8 @ 1800$ \\
Maximum engine speed, rpm & 3000 \\
Cooling system & Forced air cooling \\
\hline
\end{tabular}

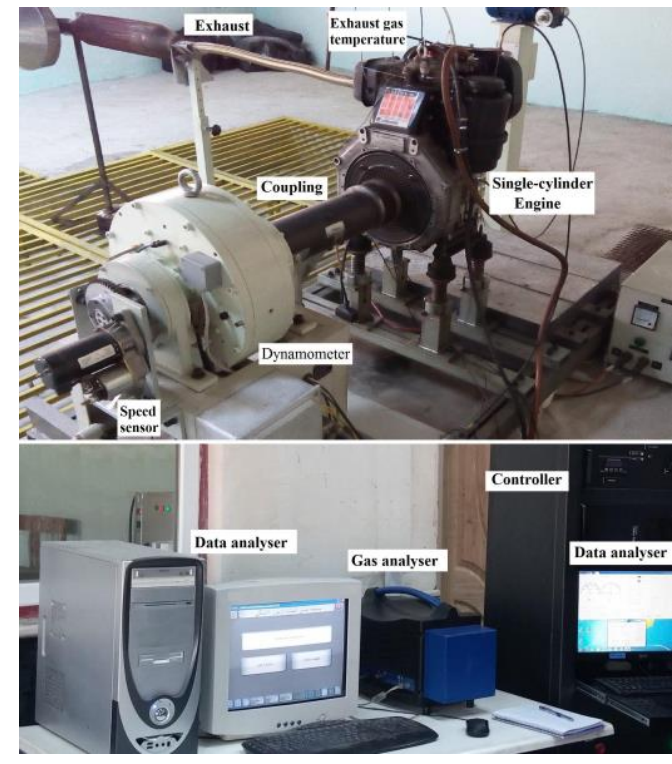

Fig. 3. Engine test laboratory setup.

\section{RESULTS AND DISCUSSION}

\subsection{Fuel Characterisation}

Fatty acid methyl esters (FAMEs) analysis is a substantial tool for recognising the composition of MCV methyl ester. The FTIR spectrum which is shown in Fig. 4 is used for confirming the perfect synthesis of biodiesel from triglycerides. Since the only change in the 
oil structure is replacing the glycerine with methanol in the hydrocarbon chain, the FTIR methyl ester spectrum was quite similar to triglyceride oils.

The GC-MS result of MCV methyl ester which was diagnosed by chromatography (using Technologies Agilent GC device) is summarised in Table 3. The higher concentration of FAMEs in MCV biodiesel were oleic and linoleic acids, which were respectively $21.8 \%$ and $31.6 \%$. High levels of oleic acid (longer chain length) led to better oxidative stability while shorter chain length reduced $\mathrm{NO}_{\mathrm{x}}$ emissions [45]. Moreover, longer carbon chain length increased the cetane number and viscosity of the fuel.

TABLE 3. FATTY ACID COMPOSITION OF MCV

\begin{tabular}{lll}
\hline Fatty acids & Chemical formula & Contents, \% \\
\hline C16:0 (palmitic) & $\mathrm{C}_{16} \mathrm{H}_{32} \mathrm{O}_{2}$ & 16.5 \\
C16:1 (palmitoleic) & $\mathrm{C}_{16} \mathrm{H}_{30} \mathrm{O}_{2}$ & 1.60 \\
C18:0 (stearic) & $\mathrm{C}_{18} \mathrm{H}_{36} \mathrm{O}_{2}$ & 10.4 \\
$\mathrm{C} 18: 1$ (oleic) & $\mathrm{C}_{18} \mathrm{H}_{34} \mathrm{O}_{2}$ & 21.8 \\
C18:2 (linoleic) & $\mathrm{C}_{18} \mathrm{H}_{32} \mathrm{O}_{2}$ & 31.6 \\
C18:3 (linolenic) & $\mathrm{C}_{18} \mathrm{H}_{30} \mathrm{O}_{2}$ & 13.2 \\
Other & - & 4.90 \\
\hline
\end{tabular}

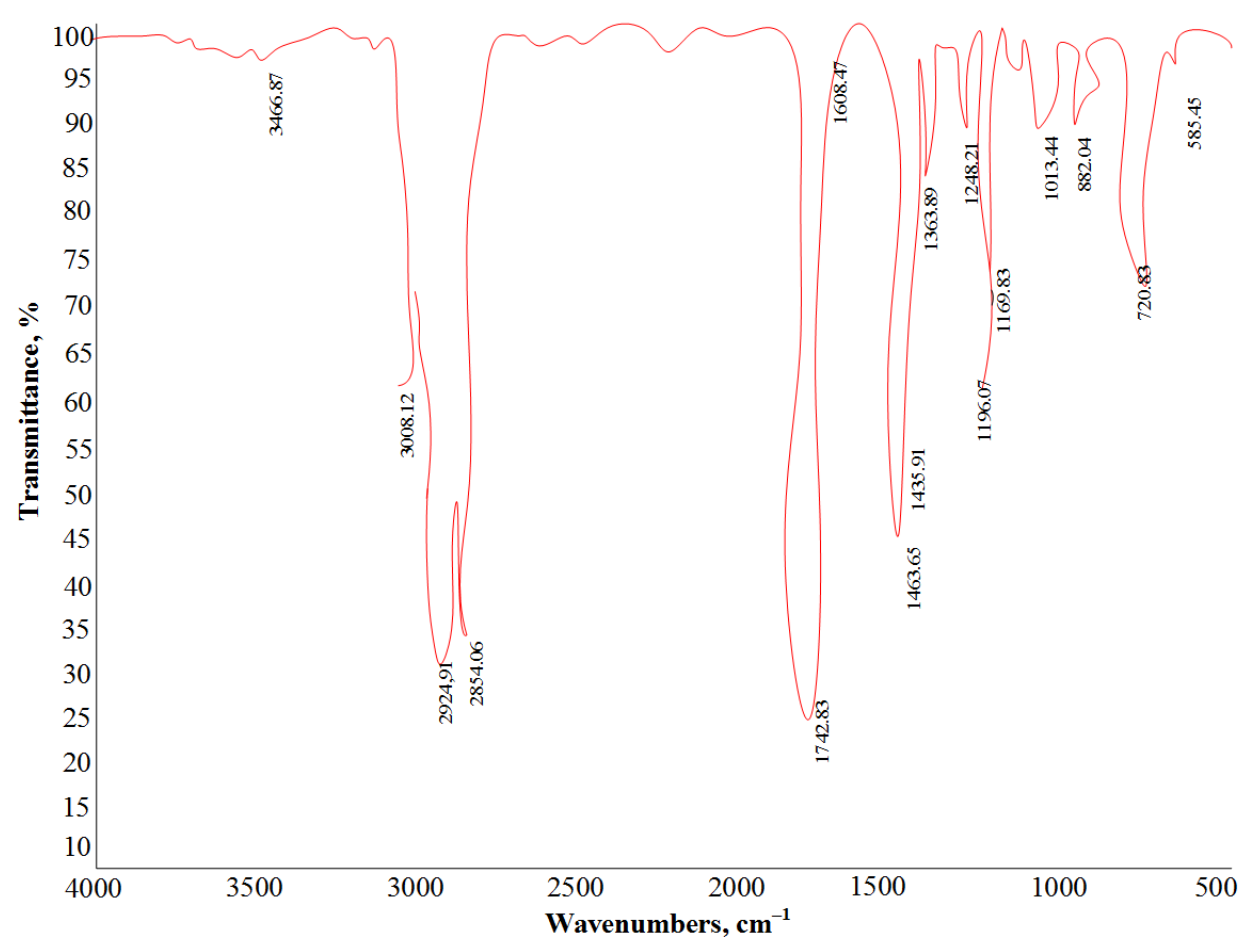

Fig. 4. FTIR spectrum of MCV methyl ester. 
Table 4 shows the most important physical properties of MCV methyl esters compare with diesel and ASTM standard. Energy density which is expressed as the heating value $\left(\mathrm{kJ} \cdot \mathrm{g}^{-1}\right)$ is one of the important parameters for recognising the quality of fuel. MCV biodiesel had a lower carbon content and a larger amount of oxygen, which justified $18.3 \%$ lower heating value than diesel. Moreover, the cetane number of MCV biodiesel was higher than the limit minimum of ASTM due to its higher oxygen content. The higher cetane number provides a lower delay period and smoother engine operation [46]. Furthermore, the MCV viscosity with $3.7 \mathrm{~mm}^{2} \cdot \mathrm{s}^{-1}$ was in the standard range $\left(1.9-6.0 \mathrm{~mm}^{2} \cdot \mathrm{s}^{-1}\right)$.

TABLE 4. PHYSICAL PROPERTIES OF MCV BIODIESEL IN COMPARISON WITH ASTM STANDARD AND DIESEL

\begin{tabular}{llll}
\hline Property & ASTM standard & Diesel & Microalgae biodiesel \\
\hline Flash point, ${ }^{\circ} \mathrm{C}$ & $120, \mathrm{~min}$. & 88 & 124 \\
Pour point, ${ }^{\circ} \mathrm{C}$ & -10 to -15 & -7 & -15 \\
Density, $\mathrm{g} / \mathrm{cm}^{3}$ & $0.86-0.90$ & 0.83 & 0.86 \\
Viscosity, cSt & $1.9-6.0$ & 3.1 & 3.7 \\
Sulphur content, $\%$ & $0.15 \mathrm{max}$. & $\mathrm{N} / \mathrm{A}$ & $\mathrm{N} / \mathrm{A}$ \\
Acid value, $\mathrm{mg} \mathrm{KOH} / \mathrm{g}$ & 0.8 & $\mathrm{~N} / \mathrm{A}$ & 0.4 \\
Cetane number & 47 min. & 46.2 & 51.4 \\
Calorific value, $\mathrm{MJ} / \mathrm{kg}$ & N/A & 46.8 & 38.7 \\
\hline
\end{tabular}

\subsection{Exhaust Emission Results}

Undesirable engine emissions including $\mathrm{CO}, \mathrm{CO}_{2}, \mathrm{HC}$, and $\mathrm{NOx}$ were measured in three different loads for B10 and B20 blends of MCV biodiesel and compared with pure diesel. It has been observed that engine emissions and performance depend on pure diesel and biodiesel's physical and chemical properties, engine type and operating conditions [47].

$\mathrm{HC}$ emissions are depicted in Fig. 5 at different engine speeds for MCV biodiesel blends and pure diesel. Based on the results, $\mathrm{HC}$ emissions decreased for all three loads by increasing the biodiesel blends. As compared to diesel, the best $\mathrm{HC}$ emissions improvement were observed in MCV20 in which the average decrease was $45.8 \%, 48.7 \%$ and $51.1 \%$ at no-load, half-load and full-load respectively. These amounts for MVC10 were respectively $38.6 \%$, $39.6 \%$, and $59 \%$ lower than diesel. HC emissions reduction indicated a decrease in combustion delay due to higher cetane number [48].

$\mathrm{CO}$ emissions are produced due to the lack of oxygen during combustion. Fig. 6 shows $\mathrm{CO}$ emissions for MCV20 and MCV10 at different engine loads. CO emissions of MCV20 were $36.3 \%, 37.7 \%$ and $44.2 \%$ lower than pure diesel at no-load, half-load and full-load respectively. By increasing the engine load or speed and the biodiesel content, the proportion of $\mathrm{CO}$ emissions decreased owing to the rich fuel-air mixture and higher cetane number in biodiesel [48]. Besides, the average amount of $\mathrm{CO}_{2}$ emissions was decreased by raising the blend of MCV biodiesel as a result of the lower carbon to hydrogen ratio of biodiesel compared with diesel. $\mathrm{CO}_{2}$ emissions are shown in Fig. 7 for different loads. While using MCV20 as fuel, the average amount of $\mathrm{CO}_{2}$ emissions was $27.8 \%, 18.6 \%$ and $5.3 \%$ lower than pure diesel at no-load, half-load and full-load respectively. Analysing $\mathrm{CO}_{2}$ emissions stated that these emissions increase with rising engine load. 


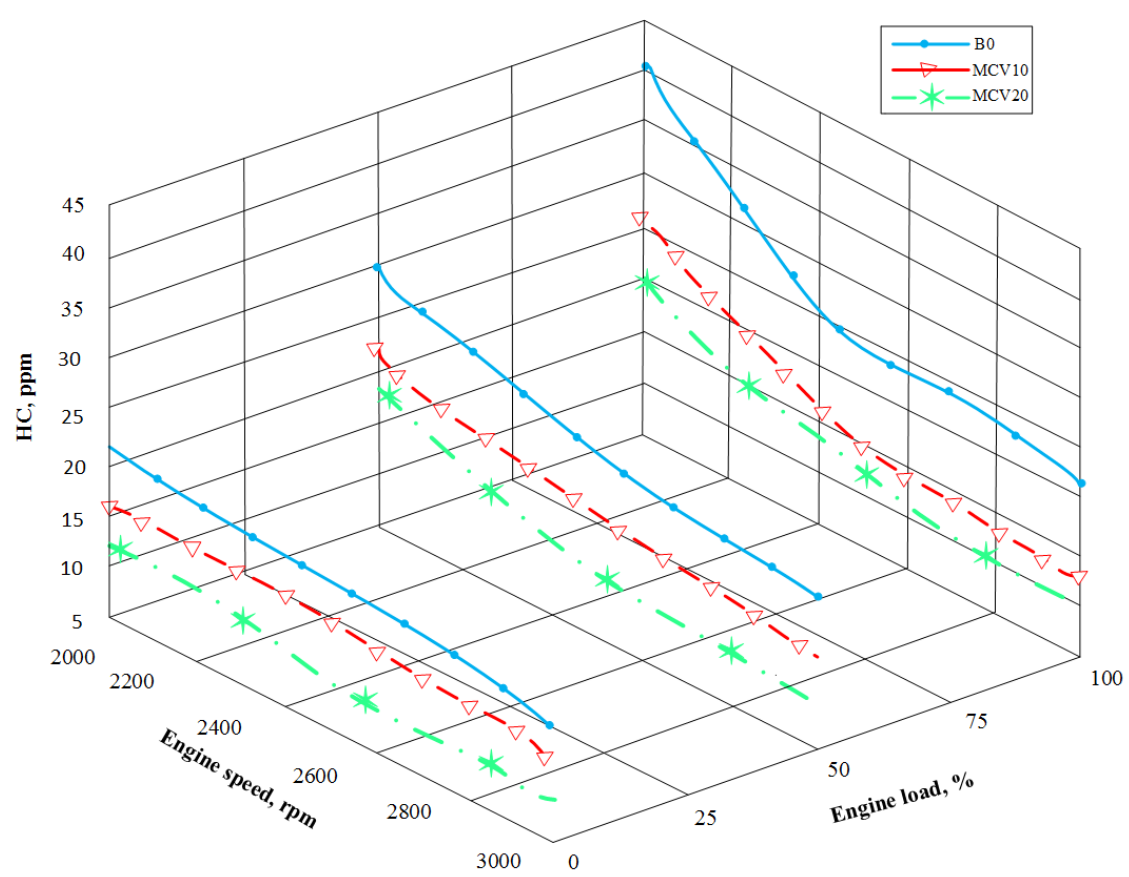

Fig. 5. HC emissions of MCV biodiesel blends at different loads/speeds.

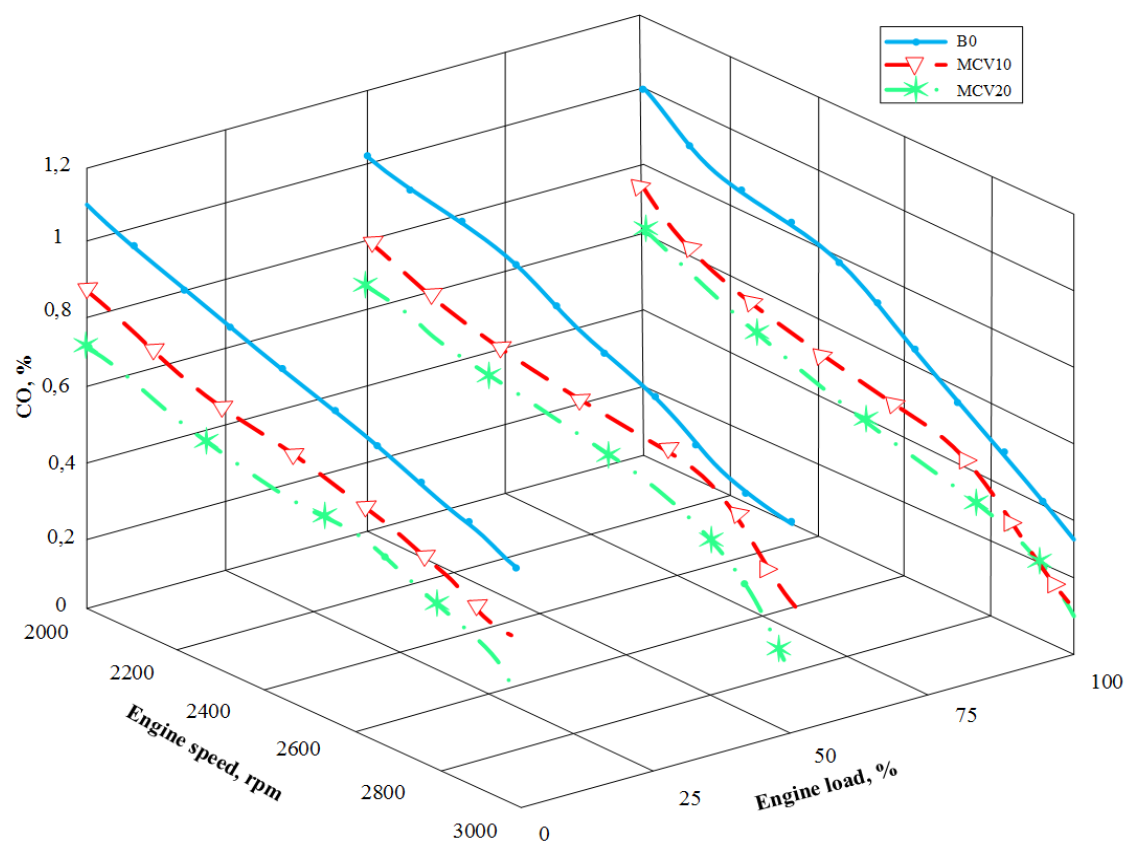

Fig. 6. CO emissions of MCV biodiesel blends at different loads/speeds. 


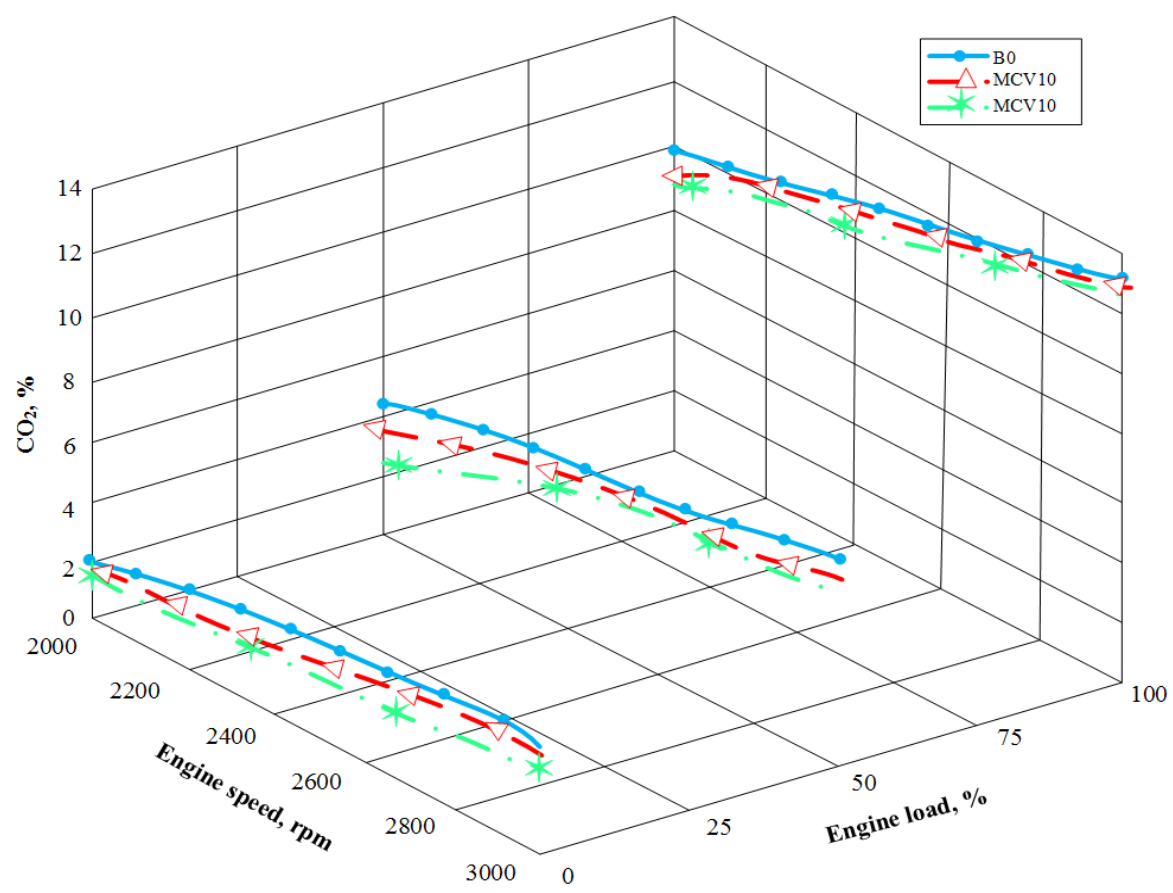

Fig. 7. $\mathrm{CO}_{2}$ emissions of $\mathrm{MCV}$ biodiesel blends at different loads/speeds.

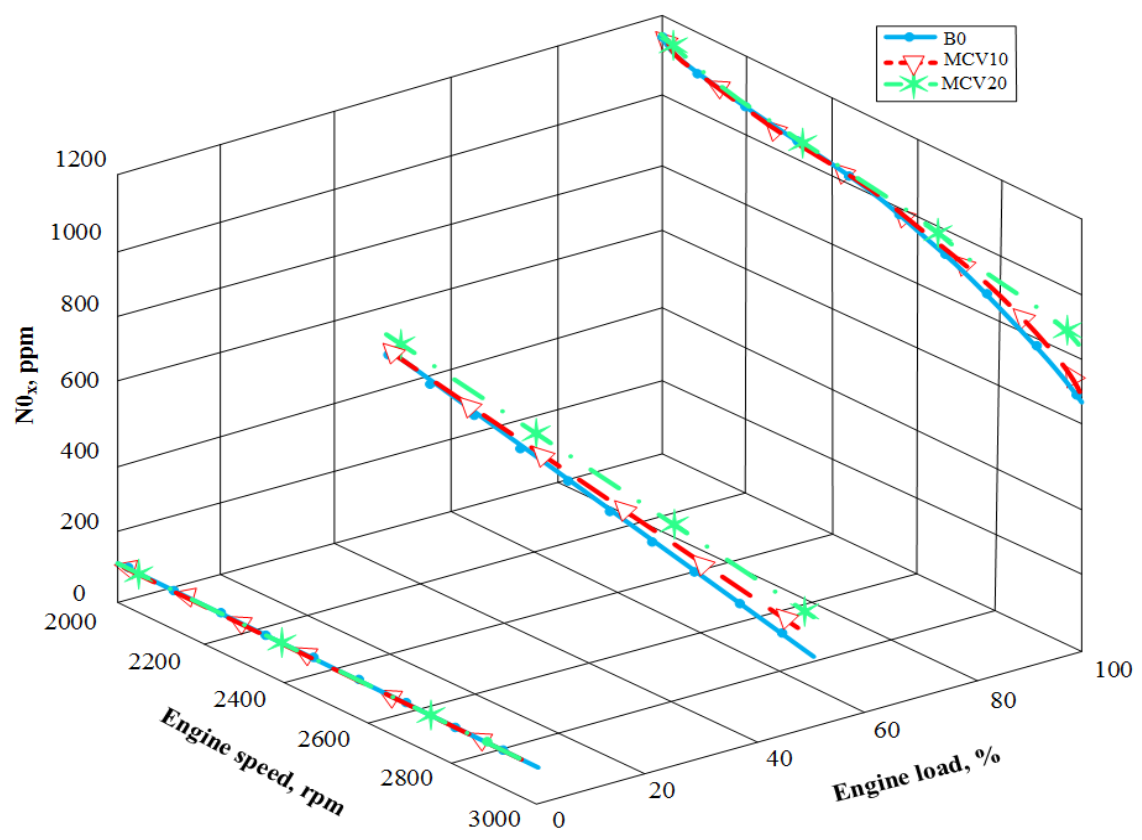

Fig. 8. $\mathrm{NO}_{\mathrm{x}}$ emissions of MCV biodiesel blends at different loads/speeds. 
The $\mathrm{NO}_{\mathrm{x}}$ emissions are highly dependent on combustion temperature, ignition delay and physicochemical properties of the fuel, and vary linearly with the engine load [47]. According to Fig. 8, the average increase in $\mathrm{NO}_{\mathrm{x}}$ emissions for MCV20 were $3.4 \%, 4.8 \%$, and $5.1 \%$ higher compared with diesel at no-load, half-load and full-load respectively. For MVC10, these amounts were respectively $3.0 \%, 4.3 \%$, and $4.7 \%$ higher than pure diesel. The higher compressibility, viscosity and density in the biodiesel blend impact injection timing and increase $\mathrm{NO}_{\mathrm{x}}$ emissions [49].

\subsection{Engine Performance Results}

Performance parameters of the engine including power, torque, and brake specific fuel consumption (BSFC) were evaluated for MCV10 and MCV20 at various engine speeds. Fig. 9 illustrates engine power and torque for MCV biodiesel compared with pure diesel. The power output which was achieved with MCV20 and MCV10 were respectively $79 \%$ and $81.2 \%$ of the average value obtained for pure diesel. The maximum power achieved from MCV20 was $6.22 \mathrm{~kW}$ at $3000 \mathrm{rpm}$ in comparison with $8.49 \mathrm{~kW}$ for pure diesel. The average reduction in engine torque for MCV20 and MCV10 were respectively $6.7 \%$ and $5.4 \%$ compared to pure diesel. The lowest torque belonged to MV20 with $20.45 \mathrm{~N} \cdot \mathrm{m}$ at $3000 \mathrm{rpm}$. Lower heating value and higher viscosity of MCV biodiesel compared with pure diesel are responsible for lower power and torque of engine especially in full-load condition [48].

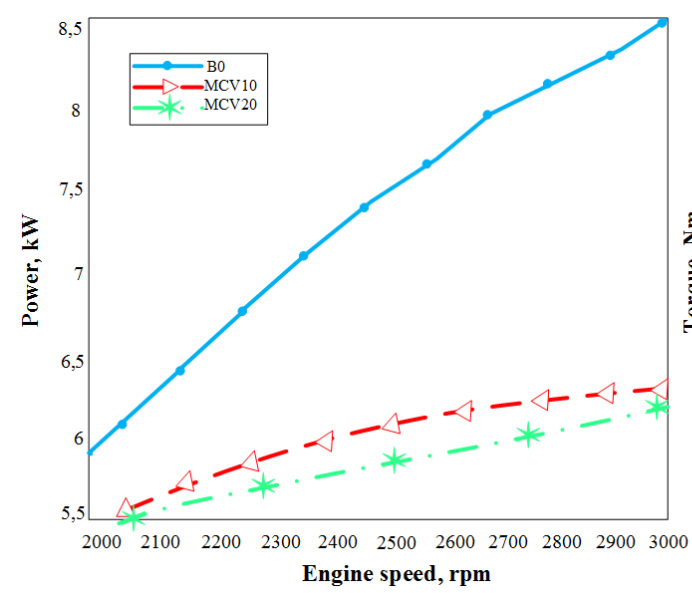

a)

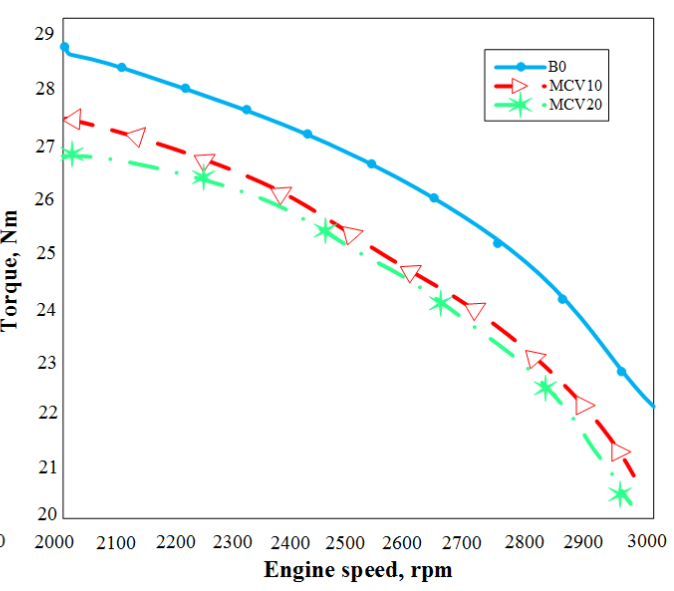

b)

Fig. 9. Power (a) and torque (b) of engine with MCV biodiesel blends at full-load.

BSFC which is the unit of fuel consumption rate per power produced is different in biodiesel blends and pure diesel due to different energy content. Fig. 10 shows BSFC of MCV biodiesel blends at half-load and full-load. As can be seen in Fig. 10, a rise in BSFC occurred by increasing the biodiesel content. The averages BSFC for MCV20 and MCV10 were respectively $15.2 \%$ and $12.6 \%$ higher than pure diesel at full-load. For half-load, these amounts were respectively $12.7 \%$ and $9.5 \%$ higher than pure diesel. Lower calorific value and higher oxygen content result in higher BSFC for MCV biodiesel blends than pure diesel.

Exhaust gas temperature of MCV biodiesel are depicted in Fig. 11. The average reductions of the exhaust gas temperature for MCV20 and MCV10 were respectively $12.2 \%$ and $9.3 \%$ 
compared with diesel. High oxygen content leads to improving combustion progress and lower exhaust gas temperature of MCV biodiesel compared with diesel.

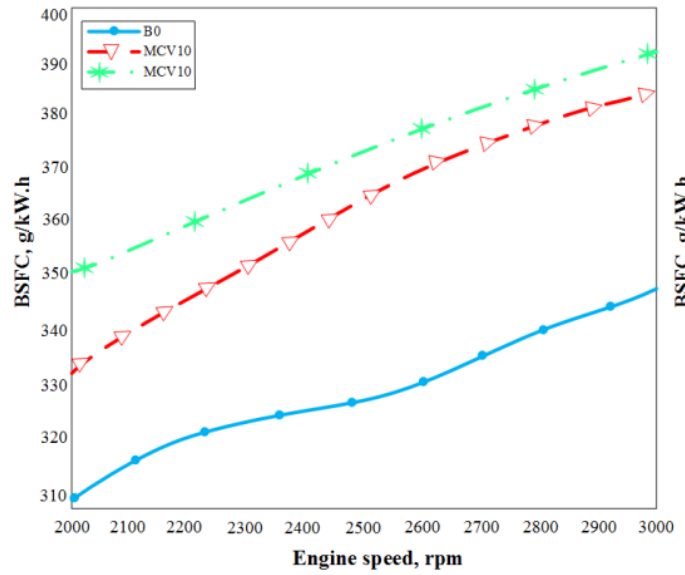

a)

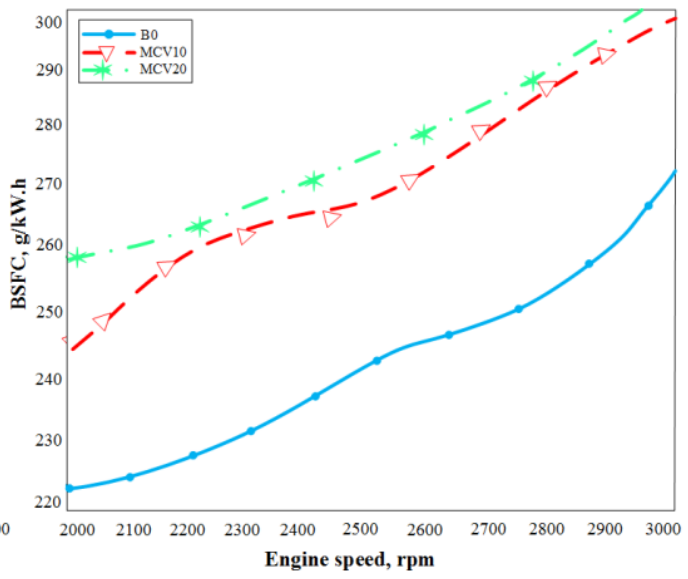

b)

Fig. 10. BSFC of MCV biodiesel blends at half-load (a) and full-load (b).

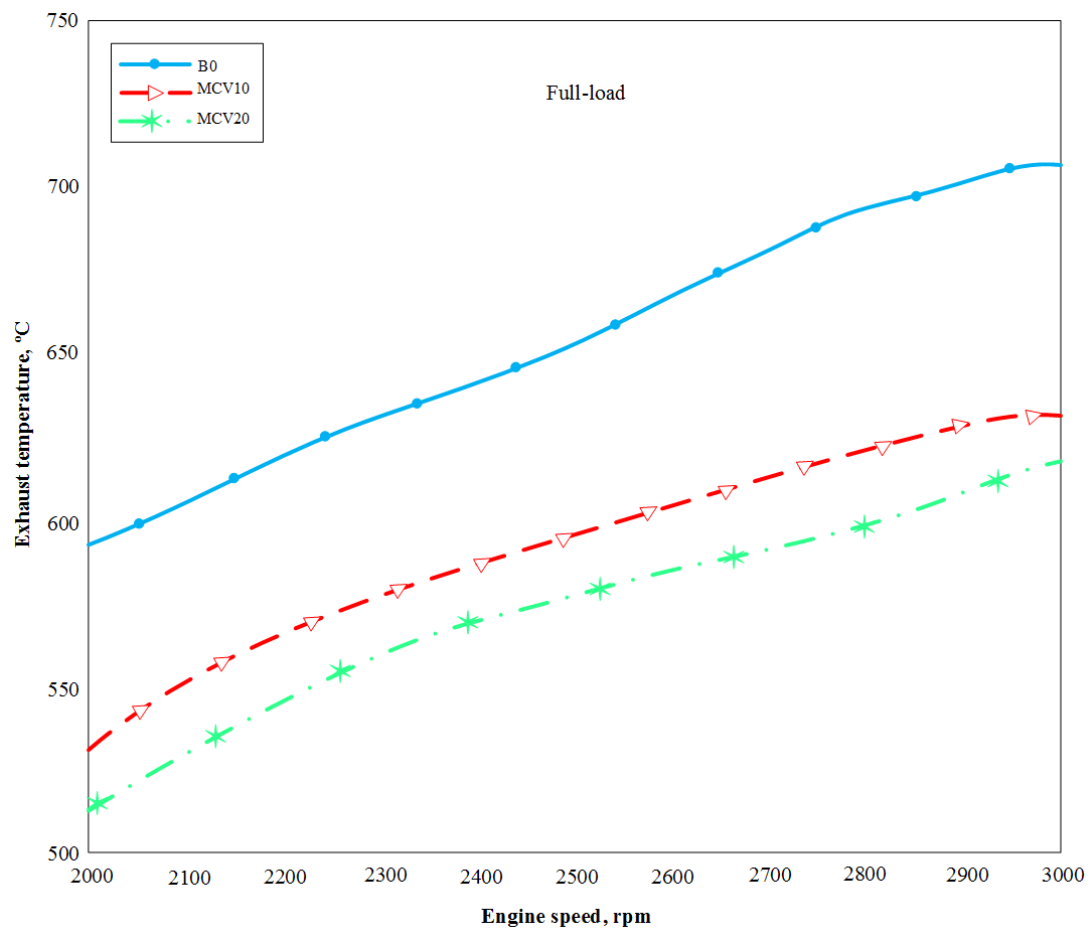

Fig. 11. Exhaust gas temperature of MCV biodiesel blends at full-load. 


\section{Conclusions}

This experimental study aimed to investigate physicochemical properties of MCV biodiesel and to evaluate emissions and performance of diesel engine fuelled with its blends at different loads/speeds. Based on the experimental results, the following conclusions can be drawn:

- The GC-MS of MCV methyl ester showed MCV contained the long carbon chain length;

- The higher FAMEs in MCV biodiesel were oleic and linoleic acid by $21.8 \%$ and $31.6 \%$;

- All physical properties of MCV biodiesel were in the range of ASTM standards;

- MCV biodiesel had a higher cetane number than pure diesel due to its higher oxygen content;

- The heating value of MCV biodiesel was $18.3 \%$ less than pure diesel;

- CO emissions of MCV20 were $44.2 \%$ lower than pure diesel at the full-load engine condition;

- MCV20 had 27.8 \%, $18.6 \%$ and $5.3 \%$ lower $\mathrm{CO}_{2}$ emissions at no-load, half-load and full-load compared with diesel respectively;

- The test analyses showed that the effect of MCV biodiesel in HC emissions was statistically significant by $51.1 \%$ reduction for MCV20;

- $\mathrm{NO}_{\mathrm{x}}$ emissions of MCV20 were $5.1 \%$ higher than pure diesel;

- MCV20 produced $79 \%$ of the average power obtained from pure diesel;

- BSFC of MCV20 was $15.2 \%$ higher than pure diesel, which is consistent with their lower calorific value and higher oxygen content.

Finally, results showed that MCV biodiesel can play an important role in the reduction of global air pollution. This superior feedstock was cultivated in wastewaters derived from municipal, agricultural and industrial activities, which potentially provides not only cost-effective but also environmentally friendly biodiesel feedstock. The performance of microalgae biofuel should not be restricted to the combustion characteristics alone, because every step of the production chain of this fuel will reduce the overall greenhouse gas emissions.

\section{REFERENCES}

[1] Demirbas A., Demirbas M. F. Algae energy: algae as a new source of biodiesel. London: Springer, 2010. https://doi.org/10.1007/978-1-84996-050-2

[2] Gulum M., Bilgin A. An Experimental Optimization Research of Methyl and Ethyl Esters Production from Safflower Oil. Environmental and Climate Technologies 2018:22(1):132-148. https://doi.org/10.2478/rtuect-2018-0009

[3] Ahmad A. L., Yasin M. N. H., Derek C. J. C., Lim J. K. Microalgae as a sustainable energy source for biodiesel production: a review. Renewable and Sustainable Energy Reviews 2011:15(1):584-593 https://doi.org/10.1016/j.rser.2010.09.018

[4] Pittman J. K., Dean A. P., Osundeko O. The potential of sustainable algal biofuel production using wastewater resources. Bioresource Technology 2011:102(1):17-25. https://doi.org/10.1016/j.biortech.2010.06.035

[5] Lam M. K., Lee K. T. Microalgae biofuels: a critical review of issues, problems and the way forward. Biotechnology Advances 2012:30(3):673-690. https://doi.org/10.1016/j.biotechadv.2011.11.008

[6] Maity J. P., Bundschuh J., Chen C.-Y., Bhattacharya P. Microalgae for third generation biofuel production, mitigation of greenhouse gas emissions and wastewater treatment: Present and future perspectives - a mini review. Energy 2014:78:104-113. https://doi.org/10.1016/j.energy.2014.04.003

[7] Elegbede I., Guerrero C. Algae biofuel in the Nigerian energy context. Environmental and Climate Technologies 2016:17:44-60. https://doi.org/10.1515/rtuect-2016-0005

[8] Qari H., Rehan M., Nizami A.-S. Key issues in microalgae biofuels: a short review. Energy Procedia 2017:142:898903. https://doi.org/10.1016/j.egypro.2017.12.144 
[9] Chen J., Li J., Dong W., Zhang X., Tyagi D. R., Drogui P., Surampalli Y. The potential of microalgae in biodiesel production. Renewable and Sustainable Energy Reviews 2018:90:336-346. https://doi.org/10.1016/j.rser.2018.03.073

[10] Mussgnug J. H., Klassen V., Schluter A., Kruse O. Microalgae as substrates for fermentative biogas production in a combined biorefinery concept. Journal of Biotechnology 2010:150(1):51-56. https://doi.org/10.1016/j.jbiotec.2010.07.030

[11] Wijffels R. H., Kruse O., Hellingwerf K. J. Potential of industrial biotechnology with cyanobacteria and eukaryotic microalgae. Current Opinion in Biotechnology 2013:24(3):405-413. https://doi.org/10.1016/j.copbio.2013.04.004

[12] Guiry M. D. How many species of algae are there? Journal of Phycology 2012:48(5):1057-1063. https://doi.org/10.1111/j.1529-8817.2012.01222.x

[13] Griffiths M. J., Harrison S. T. L. Lipid productivity as a key characteristic for choosing algal species for biodiesel production. Journal of Applied Phycology 2009:21(5):493-507. https://doi.org/10.1007/s10811-008-9392-7

[14] Al-lwayzy S. H., Yusaf T., Al-Juboori R. A. Biofuels from the fresh water microalgae Chlorella vulgaris (FWM-CV) for diesel engines. Energies 2014:7(3):1829-1851. https://doi.org/10.3390/en7031829

[15] Rodolfi L., Zittelli G. C., Bassi N., Padovani G., Biondi N., Bonini G., Tredici M. R. Microalgae for oil: Strain selection, induction of lipid synthesis and outdoor mass cultivation in a low-cost photobioreactor. Biotechnology and Bioengineering 2009:102(1):100-112. https://doi.org/10.1002/bit.22033

[16] Chan Y., Jun S.-Y., Lee J.-Y., Ahn C.-Y., Oh H.-M. Selection of microalgae for lipid production under high levels carbon dioxide. Bioresource Technology 2010:101(1):71-74. https://doi.org/10.1016/j.biortech.2009.03.030

[17] Xiaoli C., Zhao X. Enhanced removal of carbon dioxide and alleviation of dissolved oxygen accumulation in photobioreactor with bubble tank. Bioresource Technology 2012:116:360-365. https://doi.org/10.1016/j.biortech.2012.03.105

[18] Lukasz B., Patyna A., Placzek M., Witczak S. Cultivation of microalgae (Chlorella vulgaris) in laboratory photobioreactor. Economic and Environmental Studies 2016:4:843-852.

[19] Yang J., Xu M., Zhang X., Hu O., Sommerfeld M., Chen Y. Life-cycle analysis on biodiesel production from microalgae: water footprint and nutrients balance. Bioresource Technology 2011:102(1):159-165. https://doi.org/10.1016/j.biortech.2010.07.017

[20] Zhukova N. V., Aizdaicher N. A. Fatty acid composition of 15 species of marine microalgae. Phytochemistry 1995:39(2):351-356. https://doi.org/10.1016/0031-9422(94)00913-E

[21] Yousef H., Selim M. Y. E., Abdulrehman T. Combustion of algae oil methyl ester in an indirect injection diesel engine. Energy 2011:36(3):1827-1835. https://doi.org/10.1016/j.energy.2010.11.017

[22] Chen Y. H., Huang B. Y., Chiang T. H., Tang T. C. Fuel properties of microalgae (Chlorella protothecoides) oil biodiesel and its blends with petroleum diesel. Fuel 2012:94:270-273. https://doi.org/10.1016/j.fuel.2011.11.031

[23] Al-Lwayzy S. H., Yusaf T. Chlorella protothecoides microalgae as an alternative fuel for tractor diesel engines. Energies 2013:6(2):766-783. https://dx.doi.org/10.3390/en6020766

[24] Tuccar G., Aydın K. Evaluation of methyl ester of microalgae oil as fuel in a diesel engine. Fuel 2013:112:203-207. https://doi.org/10.1016/j.fuel.2013.05.016

[25] Makareviciene V., Lebedevas S., Rapalis P., Gumbyte M., Skorupskaite V., Zaglinskis J. Performance and emission characteristics of diesel fuel containing microalgae oil methyl esters. Fuel 2014:120:233-239. https://doi.org/10.1016/j.fuel.2013.11.049

[26] Ozsezen A. N., Canakci M., Turkcan A., Sayin C. Performance and combustion characteristics of a DI diesel engine fueled with waste palm oil and canola oil methyl esters. Fuel 2009:88(4):629-636 https://doi.org/10.1016/i.fuel.2008.09.023

[27] An H., Yang W. M., Maghbouli A., Li J., Chou S. K., Chua K. J. Performance, combustion and emission characteristics of biodiesel derived from waste cooking oils. Applied Energy 2013:112:493-499. https://doi.org/10.1016/j.apenergy.2012.12.044

[28] Chen Y.-H., Huang B.-Y., Chiang T.-H., Tang T.-C. Fuel properties of microalgae (Chlorella protothecoides) oil biodiesel and its blends with petroleum diesel, Fuel 2012:94:270-273. https://doi.org/10.1016/j.fuel.2011.11.031

[29] Satputaley S. S., Zodpe D. B., Deshpande N. V. Performance, combustion and emission study on CI engine using microalgae oil and microalgae oil methyl esters. Journal of the Energy Institute 2017:90(4):1-9. https://doi.org/10.1016/j.joei.2016.05.011

[30] Islam M. A., Rahman M. M., Heimann K., Nurun M. N., Ristovski Z. D., Dowell A., Thomas G., Feng B., Von Alvensleben N., Brown J. R. Combustion analysis of microalgae methyl ester in a common rail direct injection diesel engine. Fuel 2015:143:351-360. https://doi.org/10.1016/j.fuel.2014.11.063

[31] Jitesh P., Kumar S. N., Deep A., Sharma A., Gupta D. Evaluation of emission characteristics of blend of algae oil methyl ester with diesel in a medium capacity diesel engine. Technical Paper 2014:01:378, SAE International, 2014. https://doi.org/10.4271/2014-01-1378

[32] Mwangi J. K., Lee W.-J., Whang L.-M., Wu T. S., Chen W.-H., Chang J.-S., Chen C.-Y., Chen C.-L. Microalgae oil: Algae cultivation and harvest, algae residue torrefaction and diesel engine emissions tests. Aerosol and Air Quality Research 2015:15(1):81-98. https://doi.org/10.4209/aaqr.2014.10.0268 
[33] Thangavel M., Kumar T. S., Chandrasekar M., Uma L., Prabaharan D. Assessment of fuel properties, engine performance and emission characteristics of outdoor grown marine Chlorella vulgaris BDUG 91771 biodiesel. Renewable Energy 2017:105:637-646. https://doi.org/10.1016/j.renene.2016.12.090

[34] Al-lwayzy S. H., Yusaf T. Diesel engine performance and exhaust gas emissions using Microalgae Chlorella protothecoides biodiesel. Renewable Energy 2017:101:690-701. https://doi.org/10.1016/j.renene.2016.09.035

[35] Satputaley S. S., Zodpe D. B., Deshpande N. V. Performance, combustion and emission study on CI engine using microalgae oil and microalgae oil methyl esters. Journal of the Energy Institute 2017:90(4):513-521. https://doi.org/10.1016/j.joei.2016.05.011

[36] Wahlen B. D., Morgan M. R., McCurdy A. T., Willis R. M., Morgan M. D., Dye D. J., Bugbee B., Wood B. D., Seefeldt L. C. Biodiesel from microalgae, yeast, and bacteria: engine performance and exhaust emissions. Energy \& Fuels 2012:27(1):220-228. https://doi.org/10.1021/ef3012382

[37] Devendra S., Subramanian K. A., Juneja M., Singh K., Singh S., Badola R., Singh N. Investigating the effect of fuel cetane number, oxygen content, fuel density, and engine operating variables on $\mathrm{NO}_{\mathrm{x}}$ emissions of a heavy duty diesel engine. Environmental Progress \& Sustainable Energy 2017:36(1):214-221. https://doi.org/10.1002/ep.12439

[38] Devendra S., Singal S. K., Garg M. O., Maiti P., Mishra S., Ghosh P. K. Transient performance and emission characteristics of a heavy-duty diesel engine fuelled with microalga Chlorella variabilis and Jatropha curcas biodiesels. Energy Conversion and Management 2015:106:892-900. https://doi.org/10.1016/j.enconman.2015.10.023

[39] Farhad M. H., Rainey T. J., Ristovski Z., Brown R. J. Performance and exhaust emissions of diesel engines using microalgae FAME and the prospects for microalgae HTL biocrude. Renewable and Sustainable Energy Reviews 2018:82:4269-4278. https://doi.org/10.1016/j.rser.2017.06.026

[40] Scragg A. H., Morrison J., Shales S. W. The use of a fuel containing Chlorella vulgaris in a diesel engine. Enzyme and Microbial Technology 2003:33(7):884-889. https://doi.org/10.1016/j.enzmictec.2003.01.001

[41] Pulz O. Photobioreactors: production systems for phototrophic microorganisms. Applied Microbiology and Biotechnology 2001:57(3):287-293. https://doi.org/10.1007/s002530100702

[42] Bitog J. P., Lee I.-B., Lee C.-G., Kim K.-S., Hwang H.-S., Hong S.-W., Seo I.-H., Kwon K.-S., Mostafa E. Application of computational fluid dynamics for modeling and designing photobioreactors for microalgae production: a review. Computers and Electronics in Agriculture 2011:76(2):131-147. https://doi.org/10.1016/j.compag.2011.01.015

[43] Kong W., Song H., Cao Y., Yang H., Hua S., Xia C. The characteristics of biomass production, lipid accumulation and chlorophyll biosynthesis of Chlorella vulgaris under mixotrophic cultivation. African Journal of Biotechnology 2011:10(55):11620-11630.

[44] Huda Q., Rehan M., Nizami A.-S. Key issues in microalgae biofuels: a short review. Energy Procedia 2017:142:898903. https://doi.org/10.1016/j.egypro.2017.12.144

[45] Rahman M. M., Pourkhesalian A. M., Jahirul M. I., Stevanovic S., Pham P. X., Wang H., Masri A. R., Brown R. J., Ristovski Z. D. Particle emissions from biodiesels with different physical properties and chemical composition. Fuel 2014:134:201-208. https://doi.org/10.1016/j.fuel.2014.05.053

[46] Buyukkaya E. Effects of biodiesel on a DI diesel engine performance, emission and combustion characteristics. Fuel 2010:89(10):3099-3105. https://doi.org/10.1016/j.fuel.2010.05.034

[47] Mofijur M., Atabani A. E., al Masjuki H. H., Kalam M. A., Masum B. M. A study on the effects of promising edible and non-edible biodiesel feedstocks on engine performance and emissions production: A comparative evaluation. Renewable and Sustainable Energy Reviews 2013:23:391-404. https://doi.org/10.1016/j.rser.2013.03.009

[48] Ghazali W. N. M. W., Mamat R., Masjuki H. H., Gholamhassan N. Effects of biodiesel from different feedstocks on engine performance and emissions: A review. Renewable and Sustainable Energy Reviews 2015:51:585-602. https://doi.org/10.1016/j.rser.2015.06.031

[49] Murillo S., Miguez J. L., Porteiro J., Granada E., Moran J. C. Performance and exhaust emissions in the use of biodiesel in outboard diesel engines. Fuel 2007:86:1765-1771. https://doi.org/10.1016/j.fuel.2006.11.031

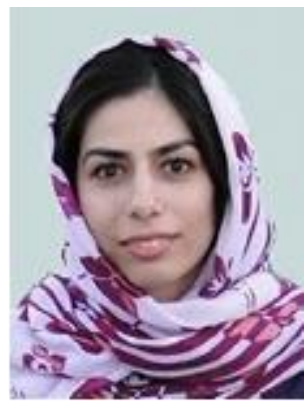

Sara Tayari received her B.S. degree in natural resources engineering from Isfahan University of Technology (IUT), Iran, in 2009. She received her Master of Science degree in environmental engineering, pollution from Islamic Azad University, Science and Research Branch (IAU) in 2014. She is currently a research consultant at the APERD Research Institute. Her main areas of interest include renewable energy sources, environmental pollution, and environmental impact assessment.

ORCID iD: https://orcid.org/0000-0002-8581-5932 

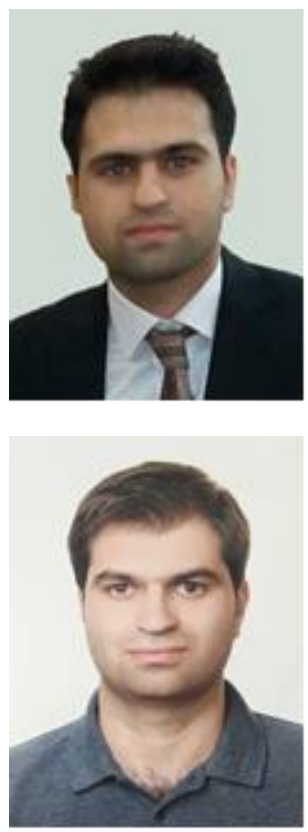

Reza Abedi received his B.S. degree in mechanical engineering from Isfahan University of Technology (IUT), Iran, in 2009. He received his M.S. degree in Automotive engineering from K. N. Toosi University of Technology, Tehran, Iran, in 2013. He has in-depth knowledge and practical experience in the field of engine technology, combustion, and vibration. Currently, Reza Abedi works as a research analyst in MLC Research and Development Center, MAPNA Group Co. in Iran.

ORCID iD: https://orcid.org/0000-0003-2645-0707

Ali Abedi graduated with a B.S in mechanical engineering from Bu Ali Sina University (BASU). Receiving his M.S. degree in 2014 from Tarbiat Modares University (TMU), he started working in Monenco consulting engineers as a designer. He is currently working in Research Institute at the Sharif University of Technology as a research scientist. ORCID iD: https://orcid.org/0000-0002-4845-1121 